\title{
Co-creation in Macrotask Knowledge Work on Online Labor Platforms'
}

I Laura Seppänen ${ }^{2}$

Chief Scientist, Finnish Institute of Occupational Health, Finland

I Clay Spinuzzi

Professor, University of Texas at Austin, USA

\section{Seppo Poutanen}

Senior Research Fellow, University of Turku, Finland

\section{Tuomo Alasoini}

Research Professor, Finnish Institute of Occupational Health, Finland

\begin{abstract}
Nordic working life studies have mostly focused on the precarious aspects of work mediated via online labor platforms. We follow a different approach and examine the potential of such work to benefit professionals by enhancing their job quality and learning. This qualitative, practice-based study applies the concept 'co-creation' to examine how a social form of creating value takes place in Upwork macrotask projects. It then investigates how platform features shape opportunities for co-creation. The data comprise interviews of 15 freelancers residing in Finland. The findings suggest that co-creation is possible in macrotask projects, but the platform does not seem to actively support co-creation. This paper provides insights into the discussion of job quality at platform work and how co-creation on platforms might be developed to support the Nordic labor market model.
\end{abstract}

\section{KEYWORDS}

Activity theory / co-creation / freelancers / innovation / knowledge work / online labor market / platform work / Upwork

\section{Introduction}

latform work, sometimes also called gig work or crowdwork, refers to work in which tasks or projects are matched on virtual platforms (for categorizations, see, e.g., Eurofound 2018; Howcroft \& Bergvall-Kåreborn 2019). Platform work offers both possibilities and challenges to workers and the Nordic labor market model, although in Nordic working life studies the precarious or exploitative aspects of such work clearly dominate the discussion (Jesnes \& Oppegaard 2020). Thus far, platform work is still marginal in the Nordic countries, though there are signs of growth in the number of online macrotask jobs, in which workers exercise high discretion and skill, providing competence that does not reside within the client's organization (Rolandsson et al. 2020). In this paper, we do not

\footnotetext{
${ }^{1}$ You can find this text and its DOI at https://tidsskrift.dk/njwls/index.

${ }^{2}$ Corresponding author: laura.seppanen@ttl.fi.
} 
focus on whether, and to what extent, such jobs constitute a threat to the Nordic labor market model, but rather, whether platform work can support workers' job quality and learning opportunities and serve Nordic values such as democracy, equity, and participation.

It can be argued that future digitalized work will increasingly require creative and social intelligence, as these are the two aspects in which even 'smart' machines will remain inferior to humans (Frey \& Osborne 2017). This emphasizes the significance of maintaining and accumulating human capital also in work mediated via online labor market (OLM) platforms. Here, we examine the extent to which macrotask jobs enhance co-creation as a mode of operation that advances such skills. As learning on platforms happens through project tasks rather than through the employment relation (Jesnes 2019), we assume that complex and challenging tasks via OLM are necessary for increasing workers' creative capabilities and well-being. The voluntary nature of platform work may evoke intrinsic motivations such as the desire to learn, which can prompt freelancers to invest great efforts into solving problems, in particular when they can choose for themselves which tasks or problems to tackle (Boudreau \& Lakhani 2013). For example, in a Finnish survey of freelancers working on OLM platform Upwork, $65 \%$ of respondents named 'learning new things' as a motive for their online work (Pajarinen et al. 2018). Co-creation, which has been discussed in existing literature under headings such as collaborative communities (Adler et al. 2008), knowledge creation (Faraj et al. 2016), communities of practice (Bodrožić \& Adler 2018; Wenger 1998), knotworking (Engeström 2005), or interactive learning (Lundvall 1992; Miettinen 2013), can be beneficial for both client organizations and the whole society.

Existing literature on the quality of platform work is limited (Wood et al. 2018) and, as referred to above, much of it emphasizes the precarious or deteriorative aspects of such work (de Stefano 2016; Deng et al. 2016; Gandini 2016; Panteli et al. 2020; Popiel 2017; Rasmussen et al., 2019; Sutherland et al. 2020; van Doorn 2017). Instead, we focus on what value the platform worker can create in co-operation with clients and possibly other workers in the Nordic context, and how this value is created: an issue rarely discussed in Nordic working life studies thus far. Specifically, we examine online macrotasks, which cannot be fully defined and controlled by the client. In such tasks, the client must rely on the worker's expertise to develop a suitable solution to the tasks. We ask how workers can co-create appropriate solutions with clients and how the platform's features can aid or hinder this co-creation, with implications for the Nordic labor market model. ${ }^{1}$ To better understand how platform workers can develop such solutions, we use activity theory to theorize them via the concept of co-creation.

Our exploratory empirical study is based on interviews of 15 people residing in Finland who have used a global platform called Upwork for gaining clients, projects, and income. The findings focus on co-creation in projects related by interviewed freelancers. Based on these findings, we suggest that co-creation is possible, but some central platform features do not seem to enhance it. Next, we discuss in greater detail the concepts of online macrotasks and co-creation.

\section{Online macrotasks}

Online labor market platforms are marketplaces that answer to two needs: clients' need to find workers to complete time-bound tasks or projects, and workers' need to find 
clients who will pay them for their time and skills. By decentralizing control to users, a platform company centralizes power through governing the transactions and data as its business model (Kornberger et al. 2017). In this triangular arrangement logic (Rolandsson et al. 2020), platforms reduce the friction in this transaction (i.e., they allow clients and workers to find each other inexpensively and to work flexibly), making this transaction peer-to-peer (i.e., clients and workers seek each other for mutual benefit) and decentralized (i.e., clients and workers contact each other directly through the platform rather than through hierarchical service providers) (cf. Acquier et al. 2017).

Platform work is typically divided into two kinds of tasks by their skills requirements. 'Microtasks' (Gegenhuber et al. 2020; Howcroft \& Bergvall-Kåreborn 2019; Rolandsson et al. 2020; Sutherland et al. 2020), 'microwork' (Panteli et al. 2020; Wood et al. 2019), and 'low-skilled work' (Jesnes 2019) comprise tasks that require low discretion and skill. These are highly defined and determined by the client or platform and often fragmented. Examples include food delivery, household help, data entry, lead generation, and basic website curation. Most studies of platform work, particularly in Nordic countries, focus on low-skilled work (Jesnes 2020).

In contrast, some other tasks mediated via labor platforms comprise specialized professional labor that in earlier decades would be performed in-house, but that has been outsourced (Rolandsson et al. 2020). Examples include translation (Rolandsson et al. 2020) as well as engineering, marketing, web and desktop development, industrial design, law and data analytics (Sutherland et al. 2020, p. 461). In the literature, these are called 'macrotasks' (Gegenhuber et al. 2020) or 'skilled' or 'high-skilled tasks' (Howcroft \& Bergvall-Kåreborn 2019; Jesnes 2020; Panteli et al. 2020; Rolandsson et al. 2020; Sutherland et al, 2020; Wood et al. 2019). Sutherland et al. (2020, p. 461) specifically argue that the global Upwork OLM platform is a hub for such macrotasks. These macrotasks, they argue, require work literacy that is 'generated, updated and maintained when workers shape solutions to problems at hand and engage with new ways of knowing'. Often, there are no standard or clearly right or wrong solutions for macrotasks (Gerber \& Krzywdzinski 2019; Wood et al. 2018). Our focus is on macrotask knowledge work on OLM platforms in which workers have more agency in shaping their work outcomes and in appropriating digital platforms to their advantage than in microtasks (Sutherland et al. 2020; Wood et al. 2018).

We see these macrotasks as a manifestation of post-bureaucratic work (Barley \& Kunda 2001), in which expertise is distributed outside bureaucracies, organizations, and hierarchies to complete interdisciplinary projects. Such work is organized around the project; leadership rotates among specialists within different phases of a project; and work is not organized sequentially and hierarchically in different and separate stages of production. At the end of the project, the project team disperses. As Grabher (2004 p. 104) argues, this projectification is central to new industries which design work around projects and emergent objects, such as software, digital media, and business consulting. In such industries, clients play a crucial role in commissioning interprofessional teams to work on creating new or redesigning existing products or services.

Following the logic of markets, platforms are based on low-information, highvelocity transactions that are inclined to accelerate the production process (Spinuzzi 2015, p. 148). Markets generate strong incentives to create knowledge, but only under strong appropriability regimes that impede the socially optimal dissemination of knowledge (Adler et al. 2008). We consider 'socially optimal dissemination' here a quality that 
supports the persistence of the Nordic labor market model (Steen et al. 2019), contributing to general social capital and trust, making economic transaction easier and more reliable, and enhancing creative collaboration between different professionals and social groups (Miettinen 2013, p. 10). Co-creation, the central interest of this paper, assumedly contributes to this kind of model.

\section{Co-creation}

As manifestations of post-bureaucratic work, macrotasks may involve co-creation. For the purpose of this paper, we develop the concept of co-creation with an activity theoretical notion of object of activity and form of interaction. Activity theory was developed in the Nordic countries to understand labor in the context of the rapid changes to working life in the late 1980s and early 1990s (Engeström 1999).

In activity theory, human conduct is seen as object-oriented activity where an object is transformed, both materially and discursively, into an outcome or a product. The object includes the culturally formed collective and societal aim of an activity (Engeström 1999), and it is similar to Karin Knorr-Cetina's (1997, p. 9) notion in which 'objects serve as centering and integrating devices for regimes of expertise'. An entity of the outside world becomes an object as it meets a human need. In this need-related capacity, the object gains motivating force that gives shape and direction to activity (Engeström, 1999).

Platform work offers knowledge workers multiple new objects on which to work. Projects and tasks on OLM platforms each have their objects. As ideal types, routine microtasks have explicitly defined and differentiated objects. Objects in co-creative OLM macrotasks are open-ended, emergent, and complex (Spinuzzi, 2015, p. 155). Personal engagement with the motivating objects embedded in practices appears to be a distinguishing aspect of expert work (Edwards 2012).

Beside objects, an activity involves other elements: a subject (individual), tools, rules, community, and division of labor (Engeström 1999). These systemic structural elements are integrated in an activity: when one element changes, it requires changes in the other elements too. Rather than considering all these elements in our analysis, we condense the elements of rules, community and division of labor into one concept: interaction. We follow activity theory's idea of activity's integrated structure in that the type of the object and the form of interaction are closely integrated and dynamically co-evolve together.

In macrotask co-creation, use value is produced jointly between clients and knowledge worker(s). The complexity and open-endedness of the objects requires collaboration kind of interaction, which means peer-to-peer work toward a shared objective or object. Simultaneously, co-creation turns the market logic into forums where use value is produced by and for all parties (Ramaswamy \& Gouillart 2011). Collaboration implies individuals' efforts to understand and construct the joint object through dialog and negotiation and to act on them (Spinuzzi 2015, p. 5). This is different from standardized, quick coordination with minimal communication in ideal microtasks. Activity theory suggests that the open-ended or defined nature of the object is closely linked with the form of interaction (quick coordination vs. joint, dialogic collaboration). Co-creation is an operation model where complex, open-ended, or evolving objects are integrated with collaboration.

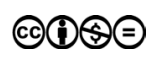


In OLMs, digital platforms afford users with technological devices, but they also mediate, organize and structure workers' and clients' activities and interaction in many ways (Eurofound 2018; Jesnes \& Oppegaard 2020; Seppänen \& Poutanen 2020; Vallas $\&$ Schor 2020) (Figure 1). On OLM platforms, work, including interaction, is digitally mediated through the Internet and digital devices, and workers practically never meet their clients face-to-face.

\section{Co-creation as research interest and question}

We can condense the central features of co-creation as follows:

- Ambiguous or emerging, relatively open-ended objects of work tasks/projects

- Collaborative interaction between at least two actors

- Contribution and engagement of freelancers

- Use value for both freelancers and clients

We investigate co-creation as reported by knowledge workers in their OLM platformorganized work context. The empirical research questions of this paper are:

1. How do platform knowledge workers co-create appropriate solutions with others as they complete macrotasks?

2. How do the platform's features aid or hinder this co-creation?

With these questions, the aim is to better understand co-creation as part of job quality in macrotask online platform work and its potentials in the context of the Nordic labor market model. Next, we describe our data and methods.

\section{Data and methods}

\section{Upwork}

Upwork, one of the world's largest freelancing websites, aims to create '... economic and social value on a global scale by providing a trusted online workplace in which to connect, collaborate and succeed' (Upwork.com 2018). It is a mid-tier platform that spans a wide range of projects in terms of skills and expertise. Upwork's platform functioning from the perspective of project success has been studied elsewhere (Claussen et al. 2018) and Pajarinen et al. (2018) have investigated the characteristics of Finnish Upworkers. Previously, Sutherland et al. (2020) studied Upworkers as showcases of 'skilled knowledge work' and Popiel (2017) investigated freelancing on Upwork in a historical context of 'flexible accumulation'.

Platform features such as work categories, keywords, and filters are central for algorithm-managed matching, which help clients choose freelancers for their projects. Freelancers craft their public profiles on the platform and may do tests free of charge to prove their skills. Upwork also offers processes of conflict resolution for users (Figure 1). 
Figure I Main Upwork features mediating the relation between freelancers and clients. The features analyzed in this study are shaded.

\section{Client's contact zone}

Filters for clients

Call for offers; direct invitations

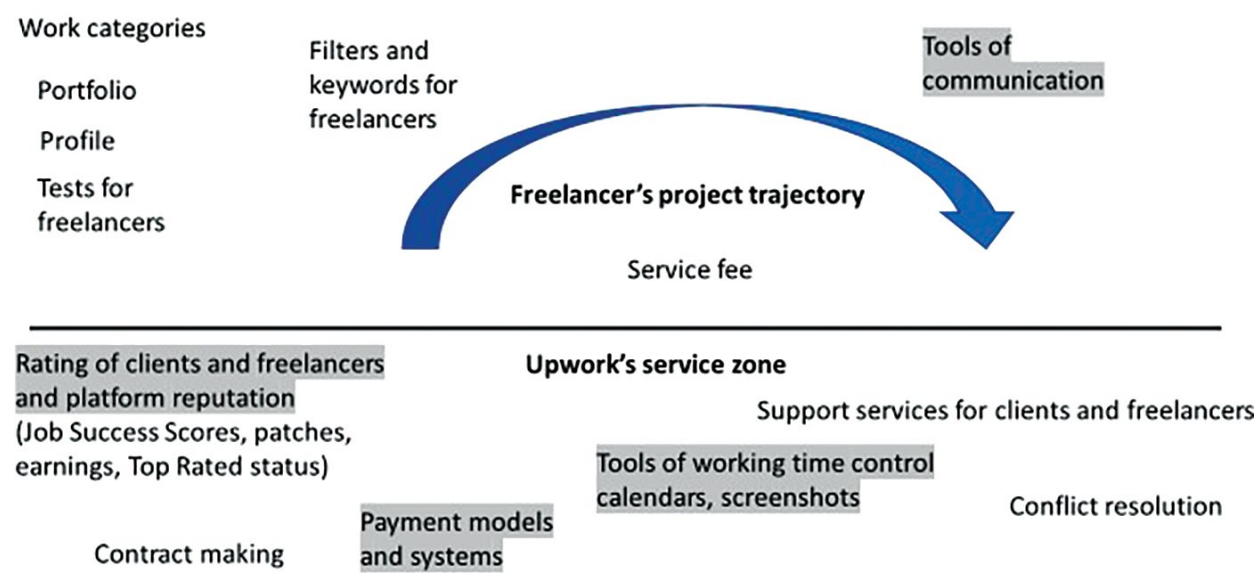

Upwork, besides being a fast-tempo marketplace, also functions as a flat online network structure that potentially enhances co-creation. First, Upwork's diminishing provision system, in which the fee percentage is smaller when more money passes between a client and freelancer, may encourage freelancers to create long-term relations that are favorable to co-creation. Second, the rating system is bi-directional, so that both clients and freelancers give each other scores. Such system enhances trust. Third, Upwork functions in a horizontal peer-to-peer style that may enhance joint problem-solving and co-creation.

Rating and reputation are indispensable for building necessary trust between strangers on a global scale. On Upwork, the main means for reputation is a Job Success Score (JSS) based on client feedback, produced by algorithms in a complex way and added to a freelancer's profile. The dynamic JSS strongly influences the order in which freelancers are shown to clients and their reputation on the site.

Most Upwork processes for managing or administering projects are relatively welldefined in terms of client and freelancer, resembling microtask work: A client makes a direct invitation or posts an offer openly, the freelancer bids for it, and if it is accepted, a contract with requirements, payment and timetable is drawn up. The freelancer completes the task and sends it to the client, and after the client's approval, the freelancer gets her money.

\section{Data collection}

The respondents of a survey of Upworkers in Finland (Pajarinen et al. 2018) who had shown an interest in being interviewed were contacted outside Upwork. All 15 volunteers 
were interviewed in two rounds. In the first round (between June and November 2018), the first nine semi-structured interviews were conducted. In the second round (in April and May 2019), six additional interviews focused on projects of the freelancers' choice. Except for one face-to-face interview, the rest were carried out via Skype and lasted 40-80 minutes. The thematic interviews concerned the history and role of platform work in the interviewees' lives, their Upwork projects, means of support, and possibilities for learning and career building. Table 1 shows the interviewees and their job characteristics on Upwork.

Table I Occupation category, work status, and activeness on Upwork platform of interviewees

\begin{tabular}{llll}
\hline A Interviewee & $\begin{array}{l}\text { B Occupation } \\
\text { Category }\end{array}$ & C Work status & $\begin{array}{l}\text { D Activeness } \\
\text { on Upwork }\end{array}$ \\
\hline PI Andy & Analyst & Self-employed & Daily \\
\hline P2 Beth & Translator & Self-employed & Once a week or more \\
\hline P3 Dave & Translator & Self-employed & Once a week or more \\
\hline P4 Eva & Graphic designer & Self-employed & Once or twice a month \\
\hline P5 Mike & Graphic designer & Unemployed & Less than once a month \\
\hline P6 Bob & Analyst & Student & Once a week or more \\
\hline P7Tom & Translator & Student & Once or twice a month \\
\hline P8 jim & Translator & In salaried employment. & Once a week or more \\
\hline P9 Sarah & Consultant & Self-employed & Almost daily \\
\hline P10 Sami & Scientist & In salaried employment & Once or twice a month \\
\hline P1/ Robert & Coder & Both temporarily salaried & A few times a year \\
\hline PI2 Greg & Engineering consultant & In salaried employment. & Once or twice a month \\
\hline PI3 Harry & Writer and editor & Self-employed & Once a week or more \\
\hline PI4 Stan & Consultant & Self-employed & Daily \\
\hline P15 Linda & Graphic designer & In salaried employment. & A few times a year \\
\hline
\end{tabular}

Survey results from December 2017 are considered in columns C and D. 'Self-employed' includes registered entrepreneurs: None of them had employees. Interviewees with characteristics in italics did not work on Upwork anymore at the time of the interview (2018-2019).

Our data corroborate the marked heterogeneity among labor platform workers (Vallas \& Kovalainen 2019). In addition to heterogeneity, the interviewees' work statuses and frequency of online work varied over time. Columns C and D (Table 1) refer to the interviewees' work statuses at the time they were active on Upwork: Five (in italics, Table 1) of them no longer used OLM platforms, but some of them considered returning to them a possibility, especially in a client role.

Some of the interviewees could gain most of their income through platforms, but in general, this share of their total income was quite modest (Pajarinen et al. 2018). All the interviewees also had studies, salaried work, or clients outside Upwork, with the exception of P2, who had just recently entered Upwork and become self-employed. Three (P1, $\mathrm{P} 9$, and P14) were mostly economically dependent on platforms for obtaining clients and income, but they all also had clients outside these platforms, and identified themselves as 
entrepreneurs or self-employed rather than platform workers or Upworkers. The only unemployed interviewee was not successful in gaining projects and used Upwork mainly for occupational interests without income. All the groups included people whose situation was precarious and who were considering different alternatives, weighing out safety (salaried work), and flexibility (self-employment and platform work).

\section{Data analysis}

After transcription, the data were qualitatively categorized (Ruusuvuori et al. 2010) and coded by the first author in two rounds. This took place, first by contents, and second, through an analysis of configurations (Author), the outcome of which has been reported in Seppänen and Poutanen (2020). Based on this analysis, the characteristics of co-creation were interpreted in detail. Co-creation was chosen as a topic of analysis after several times of reading the data and reflecting it in the light of literature, because it seemed to evoke freelancers' motivation and interest in platform work. It was interpreted based on what and how interviewees expressed their participation in projects and platform activities. Special attention was given to identifying the objects of activity and how they interacted with those objects and other actors. ${ }^{2}$ Upwork features, namely communication tools, payment model (fixed or hourly), and tools of control, were identified based on contents of interviews. As co-creation was mostly related to projects, we then chose to analyze the co-creation characteristics in projects as the unit of analysis. We found seven co-creative projects (Table 2). Thereafter, the first author crafted stories based on two selected projects reported by interviewees. These stories were crafted by organizing interviewees' experiences into temporal sequences (Czarniawska 2004). Particular attention was paid to platform features or other structures and tools of the projects. In addition to focusing on the characteristics of co-creation and Upwork features, the crafting of the stories also concentrated on the freelancers' lived practice. Stories hold more explanatory power when they are designed to capture a sense of the whole experience (Connelly \& Clandinin 1990).

In contrast to our selected projects, we present an example of a project that was not included in the findings. In this 10 -hour project, a freelancer, a translator, created a language test to distinguish native Finnish translators from others. He then sent the test to the client, who approved it and sent it to another, Asian freelancer to make it into an e-form. The two freelancers communicated about the e-form before it was returned to the client. Exchanges were kept to a minimum to avoid costs. Although the freelancer's work was creative with its innovative object, the interaction was mainly coordination (based on how the freelancer expressed it in the data) and the project did not involve co-creation.

\section{Findings}

On average, each interviewee talked about three to five projects in their interview (there were a total of approximately 60 projects in the data). Many of them were carried out in a standardized and automatized 'machine-like' mode, as in microtasks. It was often not possible to identify whether a project was co-creative, and therefore, we could not quantify the percentage of co-creative macrotask projects in the data. The seven co-creative 
projects found (Table 2) limited mainly to certain industries, such as engineering, software development, consulting, and graphic design.

Table 2 summarizes the findings. The first three rows demonstrate projects with cocreation between freelancer and client only, whereas in the four other projects, co-creation took place among at least two freelancers and the client or client representatives. Co-creation, our main interest, is manifested in the projects' objects and in the form of interaction (collaboration).

The objects open up various aspects of the project contents. They all show ambiguity or complexity, which means that the outcome of the project was neither known nor defined at the outset. Freelancers contributed to clients' final objectives that were longerlasting or more extensive than the object of the Upwork project.

Table 2 Co-creative macrotask projects on Upwork

\begin{tabular}{|c|c|c|c|c|}
\hline & A Length & B Object & C Collaboration & $\begin{array}{l}\text { D Direct platform } \\
\text { features and off- } \\
\text { platform structures } \\
\text { and tools used }\end{array}$ \\
\hline I Bob: Tutoring & Six months & $\begin{array}{l}\text { Enhancing } \\
\text { client's pro- } \\
\text { gramming tasks }\end{array}$ & $\begin{array}{l}\text { Joint problem } \\
\text { solving }\end{array}$ & $\begin{array}{l}\text { Communication by Skype } \\
\text { Manual work hour entry in } \\
\text { Upwork's diary } \\
\text { Upwork's payment system } \\
\text { Hourly payment }\end{array}$ \\
\hline $\begin{array}{l}2 \text { Sami: } \\
\text { Product } \\
\text { development }\end{array}$ & $\begin{array}{l}\text { More than } \\
\text { six months }\end{array}$ & $\begin{array}{l}\text { Emerging; } \\
\text { developing } \\
\text { products }\end{array}$ & Partnership & $\begin{array}{l}\text { Communication mainly } \\
\text { outside Upwork } \\
\text { NDA (non-disclosure } \\
\text { agreement) } \\
\text { Upwork's alerts for project } \\
\text { offers } \\
\text { Manual work hour entry in } \\
\text { Upwork's diary } \\
\text { Upwork's payment system } \\
\text { Excel spreadsheets in } \\
\text { Dropbox file } \\
\text { Hourly payment }\end{array}$ \\
\hline $\begin{array}{l}3 \text { Linda: } \\
\text { Graphic } \\
\text { design of a } \\
\text { webpage }\end{array}$ & Two weeks & Creating & $\begin{array}{l}\text { Creation through } \\
\text { dialogue }\end{array}$ & $\begin{array}{l}\text { Private emails and Skype } \\
\text { communication } \\
\text { Upwork's payment system } \\
\text { Fixed project payment }\end{array}$ \\
\hline $\begin{array}{l}4 \text { Jim: } \\
\text { Inventing } \\
\text { new words }\end{array}$ & Short & Creating & $\begin{array}{l}\text { Dialogue for } \\
\text { inventing new } \\
\text { official words }\end{array}$ & $\begin{array}{l}\text { Upwork's payment system } \\
\text { Fixed project payment }\end{array}$ \\
\hline $\begin{array}{l}5 \text { Robert: } \\
\text { Development } \\
\text { of software }\end{array}$ & $\begin{array}{l}\text { Design four } \\
\text { months, } \\
\text { maintenance } \\
\text { two years }\end{array}$ & $\begin{array}{l}\text { Design and } \\
\text { experimenta- } \\
\text { tion with new } \\
\text { technology. }\end{array}$ & $\begin{array}{l}\text { Two freelancers } \\
\text { and client worked } \\
\text { flexibly as a team }\end{array}$ & $\begin{array}{l}\text { Communication mainly } \\
\text { outside Upwork } \\
\text { Client's list of requirements } \\
\text { Upwork's payment system } \\
\text { Hourly payment }\end{array}$ \\
\hline
\end{tabular}


Table 2 (Continued)

\begin{tabular}{|c|c|c|c|c|}
\hline & A Length & B Object & C Collaboration & $\begin{array}{l}\text { D Direct platform } \\
\text { features and off- } \\
\text { platform structures } \\
\text { and tools used }\end{array}$ \\
\hline $\begin{array}{l}6 \text { Greg: Robot } \\
\text { development }\end{array}$ & $\begin{array}{l}\text { Design five } \\
\text { months, sala- } \\
\text { ried work } \\
\text { six months }\end{array}$ & $\begin{array}{l}\text { Complex } \\
\text { design of a } \\
\text { robot concept }\end{array}$ & $\begin{array}{l}\text { A flexible team of } \\
\text { engineers }\end{array}$ & $\begin{array}{l}\text { Complex project online } \\
\text { organization with an online } \\
\text { hired manager (outside } \\
\text { Upwork) } \\
\text { Communication outside } \\
\text { Upwork } \\
\text { Retainer in Upwork's pay- } \\
\text { ment system gave security } \\
\text { Upwork's payment system } \\
\text { Hourly paid project, then } \\
\text { salaried }\end{array}$ \\
\hline $\begin{array}{l}7 \text { Stan: } \\
\text { Marketing } \\
\text { and } \\
\text { competitor } \\
\text { research in } \\
\text { finance }\end{array}$ & $\begin{array}{l}\text { A little over } \\
\text { one year }\end{array}$ & $\begin{array}{l}\text { Evolving tasks } \\
\text { of analysis, } \\
\text { team coordina- } \\
\text { tion, and web- } \\
\text { site contents }\end{array}$ & $\begin{array}{l}\text { Teamwork and } \\
\text { flexible interaction } \\
\text { between multiple } \\
\text { teams. }\end{array}$ & $\begin{array}{l}\text { Online spaces outside } \\
\text { Upwork for within and in- } \\
\text { between teams } \\
\text { Upwork's payment system } \\
\text { Hourly payment, full time } \\
\text { project }\end{array}$ \\
\hline Indirect feature & & \multicolumn{3}{|c|}{$\begin{array}{l}\text { Good ratings by clients contributing to reputation } \\
\text { Freelancers accept modest prices }\end{array}$} \\
\hline
\end{tabular}

Digitally mediated encounters and situations, such as emails, team meetings or calls between the client and freelancer, seemed to give clients use value. Collaboration, such as joint problem-solving, dialog and working flexibly in teams, showed a horizontal, peer-to-peer kind of interaction that is typical of our definition of co-creation. Importantly, co-creative projects (Table 2) also included vertical interaction - in all of them, the paying client was finally the one who structured, led, and/or controlled the project. The client actively collaborated and took part in carrying out these projects.

To contextually understand co-creation in macrotask knowledge work on OLM platforms, we use two stories that help us describe two types of co-creative macrotask projects. We draw from other interviews to show that these stories represent types that we see across the co-creative projects. Three criteria were used for their selection. First, they represent the bilateral and multi-actor project categories described above. Second, these projects were discussed in detail during the interviews. The third criterion was that the freelancers were of different types: Sami was permanently employed elsewhere and happily conducted his platform work as a professional hobby, whereas Robert was in a more unstable position, trying out different work alternatives.

Sami's project (Table 2, row 2): A 'flexible partnership' between client and freelancer The client was an American practitioner who wanted to develop new products for specific US markets by combining different elements. He wanted to collaborate with a scientist to analyze extant literature that would support the development of the products. 
The Finnish Upworker, Sami, had a strong academic background and was alerted of the client's offer. Sami, apart from having full-time salaried work elsewhere, used Upwork projects to remain up to date in his field.

Sami had previously worked with eLance, a predecessor of Upwork in which a freelancer could mostly see competitors' names and suggested hourly prices. This had helped Sami estimate whether it would be worth applying for projects and enabled him to see the price range. However, Upwork did not have this system - by paying $\$ 10$ per month, freelancers can buy this feature on Upwork, but Sami was either unaware of this or did not use it. So, he relied on crafting a careful bid with the correct keywords and with a price that took his academic expertise into account but remained modest (\$50/hour). Upwork filters would have enabled the client to limit the offer to freelancers in the US only, but they apparently did not. Of this price, Sami paid a $20 \%$ fee to Upwork until the first $\$ 500$, after which the fee was $10 \%$.

The client accepted Sami's bid and price, and a continuous (with no ending date) hourly contract was drawn up, together with a non-disclosure agreement (NDA), stipulating that the client had full rights and ownership to the knowledge and outcomes of the project.

In addition to Sami, the client had two other people who mined references and filed them in a Microsoft Excel spreadsheet, placed in Dropbox. Sami did not collaborate with these other workers and did not even know whether they were hired through Upwork. Sami's task was to complement and synthesize knowledge from these references. First, the client and Sami communicated through Upwork's communication tool, a message board on which announcements from Upwork appear, and where Upwork can automatically control their communication. However, after some time, Sami and the client started exchanging private emails and speaking on the phone. The client did not control Sami's work through Upwork's screenshot mechanism, but could follow the outcomes of his work in the Dropbox files and access the working hour files that Sami filled in manually, on calendar-based diary provided by Upwork. This is also the basis of Upwork's hourly payment.

Weekly, Upwork paid Sami the hours worked minus his fee, according to calendarbased working time diary. The payment was automatically made from the client's credit card in hourly-based projects. A fixed fee of $2.75 \%$ was taken out of Sami's remuneration when he withdraws money from his Upwork account.

Sami described his collaboration with the client as a flexible partnership: 'I can offer my services in a peer-to-peer manner to [the client]. He is paying of course, and I'm a nice worker, but he listens to me and I've had an impact on the project's direction (...)'. At the time of the interview, the project was still ongoing and we did not know how it was rated. Sami thought that the client was happy with his work.

In Sami's project, and in other interviews that fall under this sort of partnership such as Bob's and Linda's, we see several features that promoted co-creation in the project.

Object: While the projects in the interviewee data were usually short-term, well defined, and relatively routine, Sami's project described a novel, initially ambiguous product object under development. Sami's input had made the client change the product idea, which shows how Sami developed the object and how the expertise of both parties complemented each other. The object in Bob's project (Table 2, Row 1) was continuously 
developed by finding solutions to the client's programming problems. The object in Linda's graphic design project (Table 2, Row 3) was to map out a unique webpage that would enhance the client's strategic aims and needs and be appealing, easy and logical to potential clients.

Collaboration: In Sami's project, the collaboration as flexible partnership was between freelancer and client only and involved no interaction between the freelancers. Based on all the interview data, this is very typical. More than his formal academic expertise, Sami's contribution (Adler et al. 2008) was important for co-creation. The client listened to Sami, which is not always the case. Co-creation and relaxed collaboration between client and freelancer also existed in Bob's tutoring project, in which collaboration was joint problem-solving (Table 2 Row 1). In Linda's example (Table 2, Row 3), both client's and freelancer's input, through dialog and negotiation, were essential: A key part of the freelancer's job was to draw out what the client needs, foster a dialog to help the client discover what they want, and to negotiate details.

\section{Robert's project (Table 2, row 4): Collaborating with multiple actors}

Robert, a Latin American freelancer living in Finland, had just prepared his first Upwork portfolio and done some Upwork tests free of charge to convince potential clients of his skills. He filled in and sent five project bids to start with, and the same day he was contacted by a representative of a small Western European company that wanted a new software tool to be developed for them. The client wanted to experiment with new technology and thus hired freelancers for a relatively long-term, innovative project. If the project were successful, the software would change the client's business. After various rounds of interviews by Skype, and negotiations on the project requirements, the client company hired two freelancers: Robert as the leading developer, and another from Eastern Europe. By hiring two freelancers, the company wanted to secure continuation by having more than one know the code base in case one of them later quit. The client questioned the difference between Robert's and the Eastern European colleague's price bids, but according to Robert, even his price request, \$25 an hour, was not expensive for the client. Robert was satisfied with the price because it was not his main income, and he believed that this work experience with novel technology would be good for him. Besides, as it was a long-term project, he would save time by not having to search for new short-term projects.

Both Robert and the client company were first-timers on Upwork. Robert made two contracts, one with Upwork, and another with the lawyers of the client company. At the beginning, the client gave Robert a list, in the form of an Excel file, of the tasks that needed to be done. Robert proposed task-sharing in equal amounts of working hours so that he and his colleague could work quickly and efficiently, and the client accepted this proposal.

After four months, the software was ready, and the client obtained good results from using it. The project ended with good ratings and feedback for Robert. After some time, the client company re-hired him for maintenance work when necessary, in a new hourly-based project. The company later founded their own internal IT team and thus no longer needed Robert. Robert fully understood that this was wise as the software was part of the company's core business. For Robert, not only was the project a positive experience; he was also particularly satisfied with its social relations: 'the money wasn't 
very important in that sense. I got other things that were better ... if you know what I mean, like the connections and the experience and the network'.

Through Robert's project, we can condense characteristics that feature co-creation in multi-actor projects on platforms.

Object: The object of Robert's project was ambiguous and innovative, not only because of the new technology, but also because the creation of the software would develop the whole business strategy and the practices of the client company. The software was successfully experimented with and turned out to be the core of the client's later business. According to Robert, complex, long-term projects were an exception rather than a rule in Upwork's category of software development. We also see that the object complexity often goes hand in hand with the length of the project. In Jim's project in which many freelancers invented new words for the Finnish language (Table 2, Row 4), the object was to produce ideas and build upon them by brainstorming, after which the client compiled the findings and all the freelancers received an equal share of pay. This project shows that multi-actor co-creation is possible even in short-term projects. Stan's marketing research project (Table 2, Row 7) also had an evolving project object: Valuable knowledge was created in the project, and later, the object moved from creating research knowledge to developing forms and ways of benefitting from this knowledge by sharing it.

Collaboration: In Robert's project, the client hired two freelancers for the same task. The data show that this also happened in other projects. Robert had an exceptionally collaborative relationship with his Eastern European colleague, which was guided by a division of labor planned by Robert and accepted by the client. In addition, other people external to the project, such as members of the client firm and the firms' clients, were involved in the project. Stan's marketing research project (Table 2, Row 6) also involved co-creation between various teams and actors.

The fact that Robert named social relations and connections as the most important personal outcomes of the project - he even maintained contact with the client representative after finishing working with them - suggests that trust was strong between the partners. The long-term, iterative communication may have contributed to this.

Overall, co-creative projects (Table 2) were much longer than the interviewees generally talked about. Interviewees seemed to favor long-term projects. The data show that freelancers do not often strengthen their social relations through Upwork, but that when this happens, it is mostly with clients rather than other freelancers.

It must be noted that co-creation is not always desirable for platform workers. For instance, in translation, freelancers may want to do good quality work on their own, and collaboration with clients, possibly including co-creation, is only necessary if the client does not make the specifications of the project clear enough in the offer or while drawing up the contract. The opposite is also true: Freelancers may see a need for co-creation in terms of better defining the contents or aim of the project, but clients may not.

Object complexity involving design and development responds to knowledge workers' professional interests, and collaboration with their need for clientele and other relations. In project stories presented above, both Sami and Robert engaged with clients' aims to develop the project object and contribute value. This engagement and contribution happened through collaboration and dialog either between the knowledge worker 
and the client (as in Sami's story), or between the client and knowledge workers (as in Robert's story). The findings confirm activity theory's suggestion that complex objects in macrotask projects are in practice integrated with a relatively intensive, dialogic collaboration. In the following, we focus on the impact of Upwork's platform features on co-creation.

\section{Impact of Upwork features on co-creation}

\section{Direct Upwork features and control}

During the studied projects, Upwork's payment systems and working time controls (Figure 1) were in use. All interviewees used Upwork's payment system with their clients. This is obligatory because of the Upwork fee, but it also enables users to increase their reputation and trustworthiness through showing their earnings or expenses on Upwork in their public profiles. As exchange value, payments have double value for freelancers: income and reputation. Once Sarah (Table 1) started a project with a fixed-fee contract, but the client had not put the money into Upwork's escrow system; Upwork informed Sarah of this and advised her to stop work on the project. Here, we see how Upwork protects freelancers in transactions. The fee is considered heavy, but all the interviewees were satisfied with the simplicity of Upwork's payment systems and money transfer services, ${ }^{3}$ as they diminished transaction risks and made freelancers' administration work easier. Macrotask projects with co-creation were more often paid hourly than at a fixed rate (Table 2 ). Hourly payment models have been created on platforms to specifically retain high-performing workers (Gerber \& Krzywdzinski 2019, p. 124).

According to Sami's project story, his client may have used results (literature reviews), working-hour files (through Upwork) and communication for control. This suggests that there was trust among project actors and less need for control. Use value, produced jointly through intensive collaboration and communication, is also a means of control for clients. Robert's client probably used Upwork's screenshot mechanism, which enables clients to see the freelancer's computer use during the working hours they pay for. It is of course up to the clients whether they use this option. Knowledge workers may actively avoid using Upwork's screenshot-based time control mechanism to protect their privacy (Sutherland et al. 2017, p. 467).

Freelancers did not use Upwork's communication tools with their clients in any co-creative macrotask project, which, according to many interviewees, are not very well developed. Upwork freelancers mostly seem to use other forms of communication that the clients use anyway. Upwork apparently does not restrict the use of communication tools to those provided through their platform, and this is a representative feature in all data.

Co-creative projects seem to use their own tools, which do not originate from Upwork (Table 2, Column D). For instance, a non-disclosure agreement and Excel spreadsheets in Dropbox files were used in Sami's project, and client's requirement document was central in Robert's project. Particularly multi-actor co-creative projects create their own structures, such as a complex team organization with a hired online manager in Greg's project, or various online spaces for teams in Stan's project (Table 2, Column D). Most co-creation seems to take place during the projects on Upwork, but 
the negotiation between a client and freelancer, before making the contract and starting the project, may also involve co-creation in terms of collaboratively elaborating the process, content and object, and the price and payment form.

\section{Indirect platform and project features}

In co-creative macrotask projects, it is common for freelancers to accept prices lower than their standard in exchange for gaining experience and/or reputation, or because long-term projects save time from continuous searching of projects (Table 2). Upwork's rating mechanisms and reputation-building did not directly function in the project stories, but they are still indispensable for projects and possible co-creation to take place. In Robert's project, the clients rated him well, which, mediated by Upwork's algorithms, is represented as a job success score in their public Upwork profiles. The fact that many co-creative projects took months (Table 2, Column A) also impacted their reputation positively, because freelancers' activeness enhances their Upwork scores. The amount of money gained may also be visible in their profiles, if they so wish. Directly through freelancers' profiles and indirectly through platform's algorithmic matching, a good reputation helps freelancers receive more project offers and to better influence the price of their work.

These findings suggest that Upwork provides freedom to craft and realize projects in a relatively flexible way, but that it does not seem to actively support co-creation in projects. Its sliding fee, which is smaller for long-term, more expensive projects, may encourage complex projects. On the other hand, it may be Upwork's 'not-doing' that inhibits co-creation. Most Upwork features center around money exchange between clients and freelancers and rating. Payroll and security are necessary in projects, but a platform's focus on client-freelancer monetary transactions does not explicitly enhance co-creation.

\section{Discussion}

In co-creative macrotask projects, clients not only decide the contents, but are also actively involved in carrying out the projects, which seems to be one precondition for cocreation. Also, freelancers participate in shaping the contents, organization, and division of labor of projects. This finding is contrary to the very idea of digital platforms as 'turbocharged' marketplaces in which quick, standardized projects prevail and all exchange is minimized. Clients' and freelancers' involvement are more crucial to co-creation than platform features as such. Complex or ambiguous objects, characteristic of co-creative projects, make the standardization of project processes difficult. The project tools and structures derive more from the client than from the platform (Table 2, Column D). It is clients, not the Upwork platform, that split or fragment work tasks, and our finding on the existence of co-creative projects suggests that it is also possible for clients not to split them. Contrary to Panteli et al.'s (2020) study on microworkers' bonds of attachment in their online work, this study suggests that knowledge workers may have strong bonds with clients and weak commitment to the platform.

This paper adds to the research on job quality by emphasizing the object and objective in co-creation. The findings suggest that in co-creation, use value may also create 
learning and well-being among platform workers. To our knowledge, this is a novel insight in OLM platform studies. We argue that the concept of object can reveal the intentional and motivating aspect of work contents that so often remains invisible in work and in working life studies.

Our study parallels the study of Sutherland, Jarrahi, Dunn, and Nelson (2020) on gig literacies in online freelancing, which examines the question of knowledge workers' creativity and job quality in platform work. They discovered how freelancers leverage platforms productively as components of their personal holding environments in five arenas: building reputation, self-presentation, maintaining productivity, mitigating transaction risk, and building relationships. However, while our data include similarities in how freelancers negotiate or work around platform's structures and control mechanisms, we examine the part of platform work that seems most motivating for knowledge workers on platforms: co-creative projects with their complex objects. Gig literacies that freelancers develop are necessary for them to cope with the platform, but they are instruments rather than objects or aims for their platform activity. In our data, freelancers' struggles with the platform are mostly creative, not co-creative.

\section{Co-creation, control, and the market logic}

Algorithmic control is central to the operation of online labor platforms (Wood et al. 2018). Our findings confirm this in Upwork's administering contracts and financial transactions and in the management of reputation. But the findings also show that cocreative projects, while being the most motivating part of platform work for freelancers, function relatively independently of the platform. Both payment systems and control are taken as self-evident and function 'behind the freelancers' back' or as 'domesticated' (Faraj et al. 2016), neither limiting nor supporting co-creation. This independence may be due to a tension between standardized market logic and the logic of co-creation, where platform users create their own tools and structures for projects.

The findings suggest that co-creation on OLM platform projects does happen within the confines of the market, but it yet might not be structured by market logic (which emphasizes quick transactions and well-specified project offers). To reliably intermediate between the two sides of the market, the OLM platform aims to keep these two sides separate. Co-creation, by building strong interpersonal trust between freelancers and clients, increases a platform's risk of users' disintermediation (Zhu \& Iansiti 2019), that is, users' cooperation and transactions off-platform.

While co-creation may be risky for the platform, it implies autonomy for platform workers. Autonomy is often investigated in relation to control in platform work studies (Gandini 2018; Pichault \& McKeown 2019; Vallas \& Schor 2020; Wood et al. 2018). Online remote workers appreciate that their platform work is autonomous and flexible: our interviewees report that for them, an interesting project counts more than income. Yet, this appreciation may hide a lack of 'worker power' or 'marketplace bargaining power' in this labor market (Wood et al. 2018, pp. 69-70): freelancers accept modest prices in co-creative projects perhaps because of their lack of bargaining power. Thus, while a platform's direct control in co-creative projects seems weak, co-creation allows clients to control workers in a trust-based way. 
An OLM platform can have a significant indirect influence on knowledge workers. Through projects, freelancers contribute to their own 'symbolic power' (Wood et al. 2018) on the platform by accumulating clients' ratings, which are molded by algorithms into reputation scores. Through this mechanism, the joint creation of use value in macrotask projects may have many repercussions for projects in the short run, and for workers' careers in the long run. By developing a positive reputation, successful freelancers can find opportunities to participate in interesting co-creative macrotasks that further increase their reputation and success. How creating long-term reputation affects gaining or accepting projects and building co-creation remains to be investigated. Because of the global competition, the opposite is also true: without suitable project experience, knowledge workers may lose demand and income. Thus, the same platform features may both marginalize and empower them (Deng et al. 2016): 'Because platforms allow workers to choose when and for how long they work, they often rely on the disciplinary power of the labor market rather than hierarchical authority' (Vallas $\&$ Schor 2020, p. 284). The borderline between microtasks and macrotasks on OLM platforms is not clear-cut and the extent to which also microtask OLM platform work can be co-creative remains to be further studied.

\section{Co-creation in OLM macrotasks and the Nordics}

Obvious tensions exist between the Nordic labor market model and many aspects of platform work. As Jesnes (2020, p. 11) argues, Nordic labor markets are characterized by 'strong social partners, encompassing collective bargaining systems and generous welfare states', but such features are not present in the triangular arrangement logic of platforms, which precludes collective mobilization. This challenges the traditional employment relation upon which the Nordic model is based. By focusing on co-creation, we have examined some potential upgrading characteristics of knowledge work on OLM platforms, instead of focusing on its shortcomings, such as inadequate regulation, precarity or lack of workers' collective voice. Co-creation can be one of the reasons for knowledge workers to work via platforms, despite such shortcomings. We argue that co-creation, with its potential for work upgrading and skills enhancing of knowledge workers, should also be taken into consideration when discussing the implications of platform work for the future development of the Nordic labor market models.

The platform economy is expected to transform both societies and the nature of our work. This paper contributes to scholarship in Nordic working life studies by showing the double or hybrid character of global OLM platforms in the Nordic labor market in practice. On the one hand, there is the OLM platform company that aims to increase its income and value for shareholders (Kornberger et al. 2017). Its income generation is dependent on the amount of transactions and data, both of which are collected from platform users. Co-creation can be of economic interest for the platform company if it attracts new users or maintains old ones. The indirect features (Table 2) are crucial intermediators between users' projects that, in the case of co-creation, are relatively autonomous from the users' perspective. It seems that the reputation of users on the platform is a many-sided currency in this game: It is valuable data for the platform, indispensable for freelancers in the competition, and also a powerful way for the platform to bind 
users to its activity. So far, an accumulating reputation on one OLM platform is not easily transferable to another platform.

On the other hand, the fact that platforms must be appealing to users can in some cases give alternatives to the strict market logic of platform companies. Such alternatives are of interest when thinking of how platform organizing of labor can bend into the Nordic labor market model where 'socially optimal dissemination of knowledge' would prevail. One Nordic example, very different from Upwork, is a global platform company, Solved Ltd, which offers wide-ranging expert support and facilitation in the early conceptualization of clean tech innovation projects (Solved 2016; 2019). In addition to closed, confidential projects, it has open and semi-open ones in which active people with learning or support interests can participate without remuneration. Clients participate in their closed projects, and the fee is shared on a percentual basis between the team roles of business lead, project lead, content lead, and knowledge workers. Solved and other attempts to build co-creation may be a way of responding to workers' desires for challenging tasks, as anecdotally claimed by Paul Millerd (2019) and theorized with the help of the concept 'communities of practice' in the evolution of management models (Bodrožić \& Adler 2018). The amount and quality of interference in managing control and creation online is delicate (Faraj 2016), which reflects the instability of the OLM platform structure (Vallas \& Schor 2020). We hope that our findings are of interest also for platform owners who want to profile themselves as innovative and gain competitive advantage by building co-creation-friendly environments for their contributors. This may be the case especially in the Nordic countries, which have tight labor markets for knowledge work (Steen et al. 2019).

\section{Conclusion}

It is in the interest of the Nordic countries to accumulate human capital and promote innovation and learning also in work that is mediated through OLM platforms. For this purpose, 'co-creation' with features of object of activity and collaboration were investigated in this paper to examine whether and how co-creation occurs in macrotask projects on a global OLM platform from the perspective of freelancers residing in Finland. Through co-creation, freelancers may participate in clients' long-term efforts beyond projects, which motivates them and can be conceptualized as co-created use value to freelancers. The objects or objectives of projects through platforms are closely integrated with forms of collaboration. Apart from nearly invisible or 'domesticated' (Faraj et al. 2016) payment and control systems, platform features do not seem to interfere with co-creation in projects. The algorithm-managed market logic of OLM platforms may steer users build their own project structures and tools for co-creation. Due to data limitations, these findings are tentative. The aim has been to overcome the standard 'innovation' or 'degradation of work' rhetoric by a practice-based qualitative approach to freelancers' everyday work in their projects.

Co-creation has significance for societal creation of knowledge and innovation. With their task complexity, co-creative projects may notably contribute to online workers' skills and career development. The labor market history and culture of the Nordic countries could be an advantage in designing future OLM platform models that enhance co-creation, innovation, and well-being. 


\section{Acknowledgements}

This research was part of the SWiPE research consortium 303667 and 303669, which is funded by the Strategic Research Council at the Academy of Finland (http://www. smartworkresearch.fi/). We thank the interviewees for their participation and the anonymous reviewers for their comments.

\section{References}

Acquier, A., Daudigeos, T., \& Pinkse, J. (2017). Promises and paradoxes of the sharing economy: an organizing framework, Technological Forecasting and Social Change 125(July): 1-10. doi: https://doi.org/10.1016/j.techfore.2017.07.006.

Adler, P., Kwon, S.-W., \& Heckscher, C. (2008). Professional work: the emergence of collaborative community, Organization Science 19(2): 359-376. doi: https://doi.org/10.1287/ orsc. 1070.0293 .

Barley, S. R., \& Kunda, G. (2001). Bringing work back in, Organization Science 12(1): 76-95. doi: https://doi.org/10.1287/orsc.12.1.76.10122.

Bodrožić, Z., \& Adler, P. S. (2018). The evolution of management models: a Neo-Schumpeterian theory, Administrative Science Quarterly 63(1): 85-129. doi: https://doi.org/10. 1177/0001839217704811.

Boudreau, K. J., \& Lakhani, K. R. (2013). Using the crowd as an innovation partner, Harvard Business Review April 2013: 61-69. https://hbr.org/2013/04/using-the-crowd-as-an-innovation-partner.

Claussen, J., Khashabi, P., Kretschmer, T., \& Siefried, M. (2018). Knowledge Work in the Sharing Economy: What Drives Project Success in Online Labor Markets? Available at: https://ssrn.com/abstract=3102865 or http://dx.doi.org/10.2139/ssrn.3102865.

Connelly, F. M., \& Clandinin, D. J. (1990). Stories of experience and narrative inquiry, Educational Researcher 19: 2-14. doi: https://doi.org/10.3102/0013189x019005002.

Czarniawska, B. (2004). Narratives in Social Science Research, London: Sage Publications. https://dx-doi-org.libproxy.helsinki.fi/10.4135/9781849209502.

de Stefano, V. (2016). The rise of the 'just-in-time worforce': On-demand work, crowdwork and labour protection in the 'gig-economy'. Inclusive Labour Markets, Labour Relations and Working Conditions Branch, Geneva: ILO, 2016 Conditions of Work and Employment Series No. 71.

Deng, X., Joshi, K. D., \& Galliers, R. D. (2016). The duality of empowerment and marginalization in microtask crowdsourcing: giving voice to the less powerful through value sensitive design, MIS Quarterly 40(2): 279-302. doi: https://doi.org/10.25300/ misq/2016/40.2.01.

Edwards, A. (2012). The role of common knowledge in achieving collaboration across practices, Learning, Culture and Social Interaction 1(2012): 22-32. doi: https://doi.org/ 10.1016/j.lcsi.2012.03.003.

Engeström, Y. (1999). Expansive visibilization of work: an activity-theoretical perspective, Computer Supported Cooperative Work 8: 63-93. doi: https://doi.org/10.1023/A:1008648532192.

Engeström, Y. (2005). Knotworking to create collaborative intentionality capital in fluid organizational fields. In M. M. Beyerlein, S. T. Beyerlein, \& F. A. Kennedy (Eds.), Collaborative Capital: Creating Intangible Value (pp. 307-336), Amsterdam: Elsevier. doi: https:// doi.org/10.1016/s1572-0977(05)11011-5.

Eurofound (Ed.) (2018). Employment and working conditions of selected types of platform work, Luxembourg: Publications Office of the European Union. https://www.eurofound. 
europa.eu/publications/report/2018/employment-and-working-conditions-of-selectedtypes-of-platform-work.

Faraj, S., von Krogh, G., Monteiro, E., \& Lakhani, K. R. (2016). Online community as space for knowledge flows, Information Systems Research, Articles in advance, 1-17. doi: https://doi.org/10.1287/isre.2016.0682.

Frey, C. B., \& Osborne, M. A. (2017). The future of employment: how susceptible are jobs to computerization? Technological Forecasting and Social Change 114(C): 254-280. doi: https://doi.org/10.1016/j.techfore.2016.08.019.

Gandini, A. (2018). Labour process theory and the gig economy, Human Relations 2018, online first, 1-18. doi: https://doi.org/10.1177/0018726718790002.

Gegenhuber, T., \& Schlussler, E. (2020). Microphones, not megaphones: Functional crowdworkers' voice regimes on digital work platforms, Human Relations 1-31 first online. doi: https://doi.org/10.1177/0018726720915761.

Gerber, C., \& Krzywdzinski, M. (2019). Brave new digital work? New forms of performance control in crowdwork. In S. Vallas \& A. Kovalainen (Eds.), Work and Labor in the Digital Age (pp. 121-144), Bingley, UK: Emerald Publishing Ltd. doi: https://doi.org/10.1108/ s0277-283320190000033008.

Grabher, G. (2004). Learning in projects, remembering in networks? Communality, sociality, and connectivity in project ecologies, European Urban and Regional Studies 11(2): 103-123. doi: https://doi.org/10.1177/0969776404041417.

Howcroft, D., \& Bergvall-Kåreborn, B. (2019). A typology of crowdwork platforms, Work, Employment and Society 33(1): 21-38. doi: https://doi.org/10.1177/0950017018760136.

Jesnes, K. (2019). Employment models of platform companies in Norway: a distinctive approach? Nordic Journal of Working Life Studies, 9(S6). doi: https://doi.org/10.18291/ njwls.v18299iS18296.114691.

Jesnes, K. (2020). Chapter 1. Introduction. In K. Jesnes \& S. Oppegaard (Eds.), Platform Work in the Nordic Models: Issues, Cases and Responses (pp. 11-16): TemaNord 2020:513. doi: http://dx.doi.org/10.6027/temanord2020-513.

Jesnes, K., \& Oppegaard, S. (Eds.). (2020). Platform work in the Nordic models: issues, cases and responses, TemaNord 2020:513. doi: http://dx.doi.org/10.6027/temanord2020-513.

Kornberger, M., Pflueger, D., \& Mouritsen, J. (2017). Evaluative infrastructures: Accounting for platform organization, Accounting, Organizations and Society 60(2017): 79-95. doi: http://dx.doi.org/10.1016/j.aos.2017.05.002.

Leonardi, P. M. (2011). When flexible routines meet flexible technologies: affordance, constraint, and the imbrication of human and material agencies, MIS Quarterly 35(1): 147-167. doi: https://doi.org/10.2307/23043493.

Lundvall, B.-A. (1992). National Systems of Innovation: Towards a Theory of Innovations and Interactive Learning, London: Pinter Publishers. doi: https://doi.org/10.7135/ upo9781843318903.

Miettinen, R. (2013). Innovation, Human Capabilities and Democracy. Towards an Enabling Welfare State, Oxford: Oxford University Press. doi: https://doi.org/10.1093/acprof:oso/9780199692613.001.0001.

Millerd, P. (2019). The failed promise of freelance consulting talent platforms. Available at: https://think-boundless.com/the-failed-promise-of-freelance-consulting-talent-platforms/ Accessed August 2, 2019.

Pajarinen, M., Rouvinen, P., Claussen, J., Hakanen, J., Kovalainen, A., Kretschmer, T., Poutanen, S., Siefried, M. \& Seppänen, L. (2018). Upworkers in Finland. Survey results. ETLA Report 85. https://www.etla.fi/wp-content/uploads/ETLA-Raportit-Reports-85.pdf.

Panteli, N., Rapti, A., \& Scholarios, D. (2020). 'If he just knew who we were': Microworkers' emerging bonds of attachment in a fragmented employment relationship, Work, Employment and Society 34(3): 476-494. doi: https://doi.org/10.1177/0950017019897872. 
Pichault, F., \& McKeown, T. (2019). Autonomy at work in the gig economy: analysing work status, work content and working conditions of independent professionals, New Technology, Work and Employment 34(1): 59-72. doi: https://doi.org/10.1111/ntwe.12132.

Popiel, P. (2017). 'Boundaryless' in the creative economy: assessing freelancing on Upwork, Critical Studies in Media Communication 34(3): 220-233. doi: https://doi.org/10.1080/ 15295036.2017 .1282618$.

Ramaswamy, V., \& Gouillart, F. (2010). Building the co-creative enterprise. Harvard Business Review, October 2010. doi: https://doi.org/10.21203/rs.2.15151/v2.

Rasmussen, B., \& Håpnes, T. (2012). Permanent temporariness? Changes in social contracts in knowledge work, Nordic Journal of Working Life Studies 2(1): 5-22. doi: https://doi. org/10.19154/njwls.v2i1.2349.

Rolandsson, B., Saloniemi, A., \& Saari, T. (2020). High-skilled platform work in Finland and Sweden - the case of technical translators. In K. Jesnes \& S. Oppegaard (Eds.), Platform Work in the Nordic Models: Issues, Cases and Responses (pp. 47-51), TemaNord 2020:513.

Ruusuvuori, J., Nikander, P., \& Hyvärinen, M. (Eds.). (2010). Haastattelun analyysi (Analysis of interviews, in Finnish), Tampere: Vastapaino.

Seppänen, L. \& Poutanen, S. (2020). Cultural transition in the sharing economy? Introducing platform work with activity concepts. In S. Poutanen, A. Kovalainen, \& P. Rouvinen (Eds.), Digital Work and the Platform Economy. Understanding Tasks, Skills and Capabilities in the New Era (pp. 183-202), New York and Londong: Routledge.

Solved, 2016. Interview with a Solved manager, October 19, 2016.

Solved, 2019. Available at: https://www.solved.fi/about-us/.

Spinuzzi, C. (2015). All Edge. Inside the New Workplace Networks, The University of Chicago Press. doi: https://doi.org/10.7208/chicago/9780226237015.001.0001.

Steen, J. I., Steen, J. R., Jesnes, K., \& Rotnes, R. (2019). The knowledge intensive platform economy in the Nordic countries Economics Norway and the Research Foundation FAFO. Nordic Innovation 2019. Available at: https://www.nordicinnovation.org/2019/ knowledge-intensive-platform-economy-nordic-countries.

Sutherland, W., Jarrahi, M. H., Dunn, M., \& Nelson, S. B. (2020). Work precarity and gig literacies in online freelancing, Work, Employment and Society 34(3): 457-475. doi: https:// doi.org/10.1177/0950017019886511.

Vallas, S., \& Kovalainen, A. (2019). Introduction. Taking stock of the digital revolution. In S. Vallas \& A. Kovalainen (Eds.), Work and Labor in the Digital Age, Bingley, UK: Emerald Publishing Ltd. doi: https://doi.org/10.1108/s0277-283320190000033001.

Vallas, S., \& Schor, J. B. (2020). What do platforms do? Understanding the gig economy. Annual Review of Sociology 46: 273-294. doi: https://doi.org/10.1146/annurev-soc121919-054857.

van Doorn, N. (2017). Platform labor: on the gendered and racialized exploitation of low-income service work in the 'on-demand' economy, Information, Communication and Society 20(6): 898-914. doi: https://doi.org/10.1080/1369118x.2017.1294194.

Wenger, E. (1998). Communities of Practice: Learning, Meaning and Identity, Cambridge: Cambridge University Press.

Wood, A. J., Graham, M., Lehdonvirta, V., \& Hjorth, I. (2019). Good gig, bad gig: Autonomy and algorithmic control in the global gig economy, Work, Employment and Society 33(1): 56-75. doi: https://doi.org/10.1177/0950017018785616.

Zhu, F., \& Iansiti, M. (2019). Why some platforms thrive and others don't. Harvard Business Review, January-February 2019. Available at: https://hbr.org/2019/01/why-some-platforms-thrive-and-others-dont Accessed August 2, 2019. 


\section{Notes}

${ }^{1}$ With 'feature', we mean an infrastructure where interwoven technological (material) and social processes have become interlocked and that serves as affordances or constraints for humans (Leonardi 2011).

${ }^{2}$ Operational categories used for identifying co-creation included 'interacting with the client to define the object', 'bringing one's specialty to further define it', 'being ok with an ambiguous project objective', 'team work', and 'actively developing the coordination procedures for reaching the objective'.

${ }^{3}$ Despite its simplicity, Upwork's invoicing system does not take European regulations or VAT into account, which caused extra work for our interviewees. 